Reka Buana : Jurnal Ilmiah Teknik Sipil dan Teknik Kimia, 4 (1), 2019, page 22-29

Tersedia online di https://jurnal.unitri.ac.id/index.php/rekabuana

ISSN 2503-2682 (Online)

ISSN 2503-3654 (Cetak)

\title{
Peningkatkan Mutu Minyak Goreng Curah dengan Penambahan Ekstrak Kulit Pisang Raja Sebagai Antioksidan Alami
}

\author{
Dian Yanuarita Purwaningsih 1), Daril Ridho Zuchrilah ${ }^{2)}$, dan Intan Nurmala ${ }^{3)}$ \\ 1,2,3) Jurusan Teknik Kimia-Institut Teknologi Adhi Tama Surabaya \\ e-mail:dianyp@itats.ac.id
}

\begin{abstract}
ABSTRAK
Minyak goreng merupakan salah satu kebutuhan masyarakat yang semakin hari semakin meningkat baik jumlah maupun harga. Untuk mengatasi hal tersebut, masyarakat menggunakan minyak goreng curah. Minyak goreng curah adalah minyak goreng yang memiliki kualitas maupun higienitas di bawah baku mutu SNI 3555-1998, karena tanpa kemasan yang sesuai, minyak goreng akan mudah teroksidasi. Penelitian bertujuan untuk memperbaiki kualitas minyak goreng curah menggunakan ekstrak kulit pisang raja karena kulit pisang raja mengandung antioksidan alami yaitu flavonoid. Untuk memperoleh antioksidan alami tersebut, kulit pisang raja diekstraksi menggunakan metode maserasi dengan pelarut metanol dan etil asetat. Adapun berat ekstrak yang ditambahkan ke dalam minyak goreng curah yaitu $1 ; 1,5 ; 2 ; 2,5$ gram dengan lama pengadukan yaitu 20, 40, 60 menit. Sampel kemudian dianalisis nilai bilangan asam, iod, peroksida. Hasil terbaik pada penelitian ini didapatkan pada penambahan ekstrak sebanyak 2,5 gram dan waktu pengadukan 60 menit dengan hasil bilangan asam $0,19827 \mathrm{meq} / \mathrm{kg}$, bilangan iod 1,86817 $\mathrm{meq} / \mathrm{kg}$, bilangan perosida $1,94608 \mathrm{meq} / \mathrm{kg}$.
\end{abstract}

Kata kunci : minyak goreng curah; kulit pisang raja; antioksidan alami; bilangan asam, iod, peroksida.

\section{ABSTRACT}

Cooking oil is one of the needs of the community which is increasing every day both in quantity and price. To overcome this, the community uses bulk cooking oil. Bulk cooking oil is cooking oil that has quality and bygiene under SNI 3555-1998 quality standards, because without proper packaging, cooking oil will be easily oxidized. The aim of the study was to improve the quality of bulk cooking oil using plantain skin extract because the skin of king banana contains natural antioxidants, namely flavonoids. To obtain these natural antioxidants, the skin of the king banana was extracted using the maceration method with methanol and ethyl acetate solvents. The weight of the extract added to bulk cooking oil is 1; 1.5; 2; 2.5 grams with stirring time of 20, 40, 60 minutes. The sample is then analyzed for the value of acid, iodine, peroxide. The best results in this study were obtained on the addition of 2.5 grams of extract and stirring time of 60 minutes with the acid number $0.19827 \mathrm{meq} / \mathrm{kg}$, iodine number $1.86817 \mathrm{meq} / \mathrm{kg}$, peroside number 1.94608 meq / kg.

Keywords : bulk cooking oil, plantain skin, natural antioxidants, acid numbers, iodine, peroxide. 


\section{PENDAHULUAN}

Kebutuhan akan minyak goreng dimasyarakat semakin hari semakin meningkat dan disertai pula dengan meningkatnya harga jualnya. Meningkatnya harga jual minyak goreng menyebabkan masyarakat lebih memilih untuk menggunakan minyak goreng curah yang harganya lebih murah. Minyak goreng curah merupakan minyak goreng yang dijual tanpa kemasan sehingga dari ditinjau dari kualitas maupun higienitas masih jauh di bawah minyak goreng dengan tanpa kemasan. Dengan tanpa kemasan ini membuat minyak goreng curah mudah mengalami oksidasi sehingga cepat menjadi rusak. Untuk memperbaiki kualitas minyak goreng curah, dapat dilakukan dengan cara menambahkan antioksidan yang dapat menunda atau mencegah terjadinya reaksi oksidasi radikal bebas dalam oksidasi lipid pada minyak. Antioksidan alami dapat diperoleh dari buah dan sayur yang berwarna merah, orange, kuning, dan ungu. Pada penelitian sebelumnya yang dilakukan oleh Marlina dkk pada tahun 2015 yang menambahkan ekstrak kulit manggis yang mengandung antioksidan alami pada minyak goreng curah sehingga dapat menurunkan bilangan asam dan bilangan peroksida serta dapat meningkatkan bilangan iodin.

Selain kulit manggis, kulit pisang raja juga dapat digunakan sebagai antioksidan alami, hal ini sesuai dengan hasil penelitian yang dilakukan oleh Elfira Rosa Pane pada tahun 2013 menyatakan bahwa kulit pisang raja mempunyai kandungan antioksidan yaitu senyawa flavonoid yang diperoleh melalui cara maserasi [8]. Penelitian yang dilakukan oleh Elfira Rosa Pane hanya fokus pada kandungan kulit pisang raja dan cara pengekstrakannya, dan ekstrak tersebut belum diaplikasikan, sehingga hal ini mendasari penelitian ini untuk mengembangkan pengaplikasian ekstrak kulit pisang raja untuk memperbaiki mutu minyak goreng curah.

\section{Minyak Goreng}

Minyak goreng merupakan minyak atau lemak yang berasal dari bagian tumbuhan, hewan, dan dibuat secara sintetik kemudian dimurnikan sehingga dapat digunakan untuk memasak atau menggoreng makanan.[6] Minyak goreng dikatakan baik memiliki standar mutu yang ditentukan oleh Standar Nasional Indonesia (SNI). Standar mutu tersebut yaitu SNI 3555-1998, menetapkan bahwa standar mutu minyak goreng seperti pada Tabel 1.

\section{Tabel 1 Standar Mutu Minyak Goreng}

\begin{tabular}{clcc}
\hline No. & Jenis Uji & Persyaratan & Satuan \\
\hline 1. & Warna & Kuning & - \\
\hline 2. & Bau dan Rasa & Normal & - \\
\hline 3. & Bilangan Asam & Maks. 0,3 & $\mathrm{Meq} / \mathrm{kg}$ \\
\hline 4. & Bilangan Iod & $<5$ & $\mathrm{Meq} / \mathrm{kg}$ \\
\hline $\mathbf{5 .}$ & Bilangan & Maks. 2 & $\mathrm{Meq} / \mathrm{kg}$ \\
& Peroksida & & \\
\hline
\end{tabular}

\begin{tabular}{lll}
\hline 6. Kadar Air & 0,3 & $\%$ \\
\hline
\end{tabular}

(Sumber: Standar Nasional Indonesia)

Kandungan dalam minyak goreng itu adalah asam lemak yang tersusun atas yaitu sekitar dua puluh jenis asam lemak yang berbeda. Asam lemak yang dikandung oleh minyak sangat menentukan mutu dari minyak goreng, karena asam lemak tersebut menentukan sifat kimia dan stabilitas minyak [5]. Minyak goreng yang baik adalah minyak yang mengandung asam lemak tak jenuh yang lebih banyak dibandingkan dengan kandungan asam lemak jenuhnya. [11] 
Minyak goreng rentan akan kerusakan dimana kerusakan minyak goreng tersebut akan mempengaruhi kualitas dan nilai gizi makanan yang digoreng. Salah satu kerusakan pada minyak goreng disebabkan oleh pemanasan. Pemanasan minyak goreng dengan suhu yang sangat tinggi akan menyebabkan sebagian minyak teroksidasi. Minyak yang rusak akibat proses oksidasi akan menghasilkan makanan berwarna kurang menarik dan rasa yang tidak enak, serta kerusakan beberapa vitamin dan asam lemak esensial di dalam minyak. Proses oksidasi tersebut terjadi saat minyak tersebut mengalami kontak dengan sejumlah oksigen. Reaksi oksidasi juga akan menimbulkan bau tengik pada minyak dan lemak [6]. Selain menimbulkan bau tengik, radikal bebas juga dapat terbentuk akibat oksidasi yang mempunyai dampak merusak sel dan jaringan tubuh. Hal ini disebabkan radikal bebas bersifat sangat reaktif.

\section{Antioksidan}

Antioksidan merupakan molekul yang mampu menunda, memperlambat atau mencegah proses oksidasi molekul lain [10]. Mekanisme kerja antioksidan dapat menghambat reaksi oksidasi atau menghentikan reaksi berantai pada radikal bebas dari minyak yang teroksidasi (absorbsi radikal bebas).[7] Terdapat 4 macam mekanisme reaksi yaitu:

1. Pelepasan hidrogen dari antioksidan.

2. Pelepasan elektron dari antioksidan.

3. Adisi lemak ke dalam cincin aromatik pada antioksidan.

4. Pembentukan senyawa kompleks antara lemak dan cincin aromatik dari antioksidan.

Adapun tahap-tahap reaksi oksidasi lemak atau minyak adalah sebaga berikut:
Inisiasi Radikal Lipida:

$\mathrm{RH}+{ }^{*} \mathrm{O}-\mathrm{O}^{*} \stackrel{\text { Cahaya }}{\longrightarrow} \mathrm{R} *+* \mathrm{OOH}$

Pembentukan:

$$
\mathrm{R}^{*}+* \mathrm{O}-\mathrm{O} * \rightarrow \mathrm{ROO}^{*}
$$

Propagasi :

$$
\mathrm{ROOH} \rightarrow \mathrm{RO}^{*}+\mathrm{OH}^{*}
$$

Terminasi

$$
\mathrm{RO}^{*}+\mathrm{X} \rightarrow \text { produk inaktif }
$$

Reaksi oksidasi dapat terhenti dengan penambahan antioksidan, karena energi dalam persenyawaan aktif ditampung oleh antioksidan. Contoh mekanisme penambahan antioksidan pada proses oksidasi minyak adalah sebagai berikut:

$$
\begin{aligned}
& \mathrm{R}^{*}+\mathrm{AH} \rightarrow \mathrm{RH}+\mathrm{A}^{*} \\
& \mathrm{ROO}^{*}+\mathrm{RH} \rightarrow \mathrm{ROOH}+\mathrm{R}
\end{aligned}
$$

Keterangan

ROO* : Peroksida aktif

RH : Minyak atau lemak

AH : Antioksidan

$\mathrm{R}^{*} \quad$ Asam lemak tidak jenuh aktif

Penambahan antioksidan dengan konsentrasi rendah pada lipida dapat mencegah reaksi oksidasi minyak sehingga menghalangi reaksi oksidasi pada tahap inisiasi dan propagasi. [5]

\section{Pisang Raja}

Pisang raja (Musa paradisiaca sapientum) termasuk dalam famili Musaceae atau pisang-pisangan yang memiliki banyak manfaat. Selain daging buahnya, komponen lain seperti kulitnya ternyata dapat dimanfaatkan. Kulit pisang memiliki kandungan nutrisi yang tinggi, terutama kulit jenis pisang raja.[1] Kandungan nutrisi, vitamin dan antioksidan terhadap kulit pisang raja ditunjukkan dalam Tabel 3 dan Tabel 4. 
Tabel 3 Kandungan Nutrisi Kulit Pisang

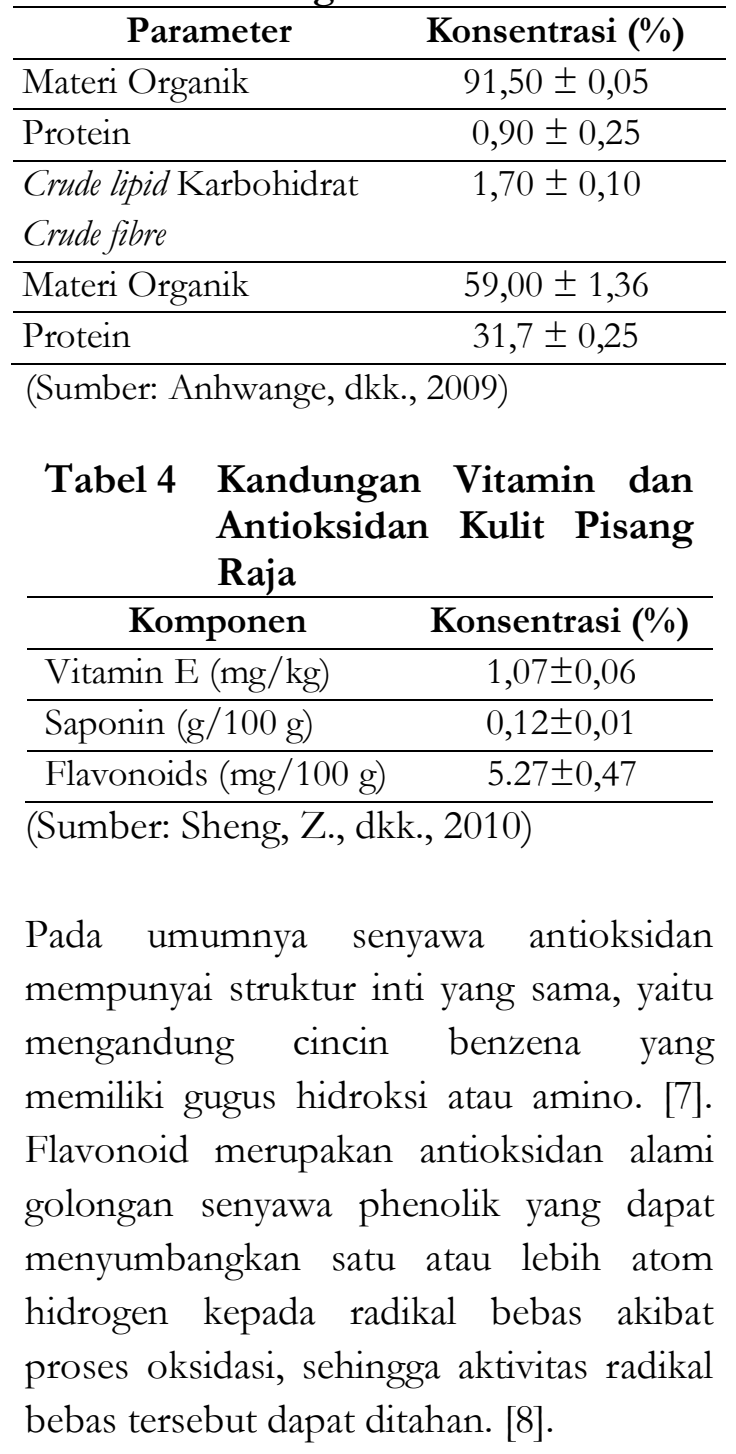

\section{METODE PENELITIAN}

Metodologi dari penelitian ini dibagi menjadi:

1. Analisa awal kualitas miyak goreng curah (bilangan asam, bilangan peroksida, bilangan iod).

2. Pembuatan/pengambilan ekstrak kulit pisang raja dengan metode meserasi mengguakan pelarut methanol dan etil asetat. Adapun langkah maserasi dalam mengambil eksstrak kulit pisang raja dapat dilihat pada Gambar 1.
3. Proses absorbsi radikal bebas dengan penambahan antioksidan alami dapat dilihat pada Gambar 2.

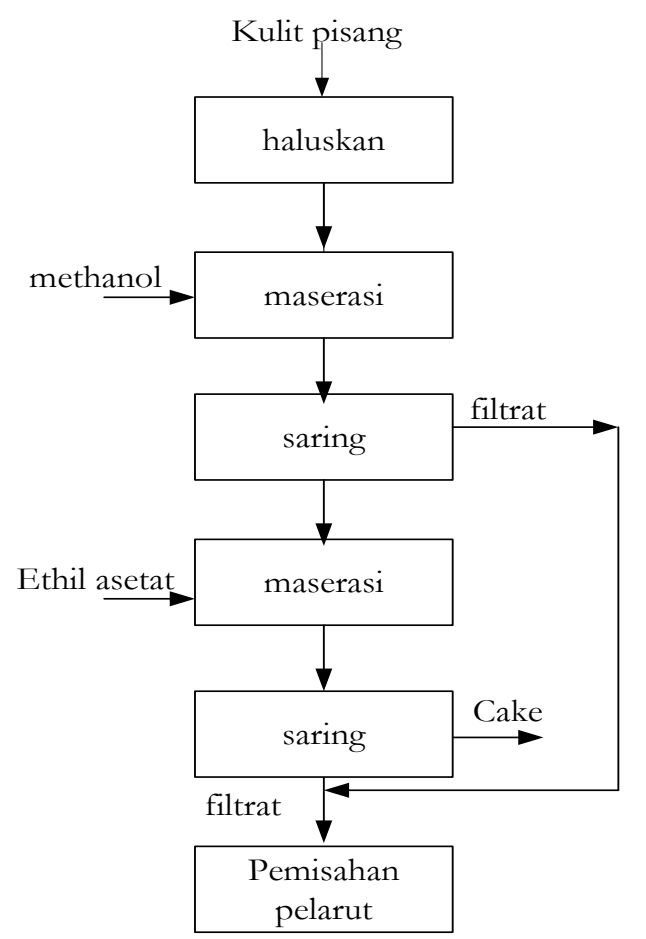

Gambar 1 Blok Diagram Ekstraksi Kulit Pisang

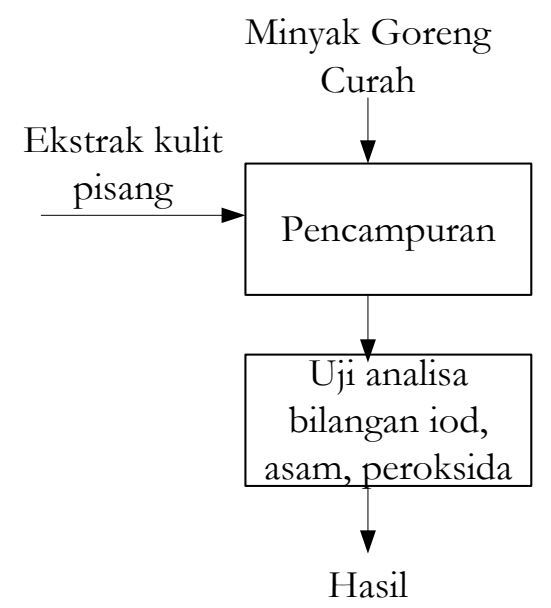

$\begin{array}{llrr}\text { Gambar 2 } & \begin{array}{l}\text { Diagram } \\ \text { Radikal Blok }\end{array} & \begin{array}{r}\text { Absorbsi } \\ \text { Bebas } \\ \text { dengan }\end{array} \\ & \text { Penambahan } & \text { Antioksidan } \\ & \text { Alami } & \end{array}$ 


\section{HASIL DAN PEMBAHASAN}

Pengaruh Penambahan Berat Ekstrak Kulit Pisang Raja dan Waktu Pengadukan Terhadap Bilangan Asam

Bilangan Asam dan bilangan peroksida pada minyak goreng menunjukan bahwa kandungan asam lemak bebas yang timbul akibat proses oksidasi. Dengan bilangan asam yang tinggi menandakan bahwa minyak goreng tersebut mengalami penurunan mutu atau kerusakan. Seperti yang disajikan pada Tabel 6 menunjukan bahwa bilangan asam dan peroksida pada minyak goreng curah melebihi baku mutu SNI yaitu $0,71836 \mathrm{meq} / \mathrm{kg}$ dan bilangan peroksida 2,12660 meq/kg.

\begin{tabular}{lll} 
Tabel 6 & Hasil Analisis & \\
\hline Parameter & SNI 3555-1998 & $\begin{array}{c}\text { Hasil } \\
\text { Analisa }\end{array}$ \\
\hline Bilangan & Maks 0,3 & 0,71836 \\
Bilangan Iod & $<5 \mathrm{meq} / \mathrm{kg}$ & 1,76192 \\
Bilangan & Maks $2 \mathrm{meq} / \mathrm{kg}$ & 2,12660 \\
Peroksida & & \\
\hline
\end{tabular}

Setelah ditambahkan ekstrak kulit pisang raja sebanyak 1 gram, bilangan asam pada minyak goreng curah turun menjadi $0,333 \mathrm{meq} / \mathrm{kg}$ seperti yang terlihat

pada

Gambar 3. Pada Gambar 3 terlihat bahwa semakin banyak penambahan berat ekstrak kulit pisang raja pada minyak goreng curah menyebabkan terjadi penurunan pada bilangan asam. Hasil terbaik analisa bilangan asam adalah pada penambahan ekstrak kulit pisang raja sebesar 2,5 gram waktu pengadukan 60 menit sebesar $0,19827 \mathrm{meq} / \mathrm{kg}$ dari $0,71836 \mathrm{meq} / \mathrm{kg}$, sehingga mengalami penurunan $72,400 \%$ yang sudah memenuhi baku mutu SNI 3555-1998 dengan bilangan asam maksimal $0,3 \mathrm{meq} / \mathrm{kg}$

Pengaruh Penambahan Berat Ekstrak Kulit Pisang Raja dan Waktu Pengadukan Terhadap Bilangan Iod

Analisis bilangan iod ini menunjukan bahwa jumlah iod yang diserap mengindikasikan banyaknya ikatan rangkap atau ikatan tidak jenuh. Pengaruh hubungan antara berat ekstrak kulit pisang raja dengan bilangan iod dengan berbagai variasi waktu dapat dilihat pada Gambar 4. Hasil analisa bilangan iod minyak goreng curah tanpa penambahan ekstrak kulit pisang raja didapatkan hasil sebesar 1,76192 meq $/ \mathrm{kg}$.

Pada saat penambahan ekstrak kulit pisang raja pada berat ekstrak 1 gram dengan waktu pengadukan 20 menit mengalami kenaikan yaitu sebesar $1,80687 \mathrm{meq} / \mathrm{kg}$, yang telah memenuhi baku mutu SNI 3555-1998 sebesar <5. Hasil yang terbaik adalah pada waktu pengadukan 60 menit dengan berat ekstrak 2,5 gram yaitu sebesar 1,87500 $\mathrm{meq} / \mathrm{kg}$, sehingga mengalami kenaikan bilangan iod sebesar 6,030\%. Kenaikan bilangan iod dikarenakan ekstrak kulit pisang raja yang ditambahakan pada minyak goreng curah dapat memperlambat kerusakan ikatan rangkap pada struktur komponen minyak. 


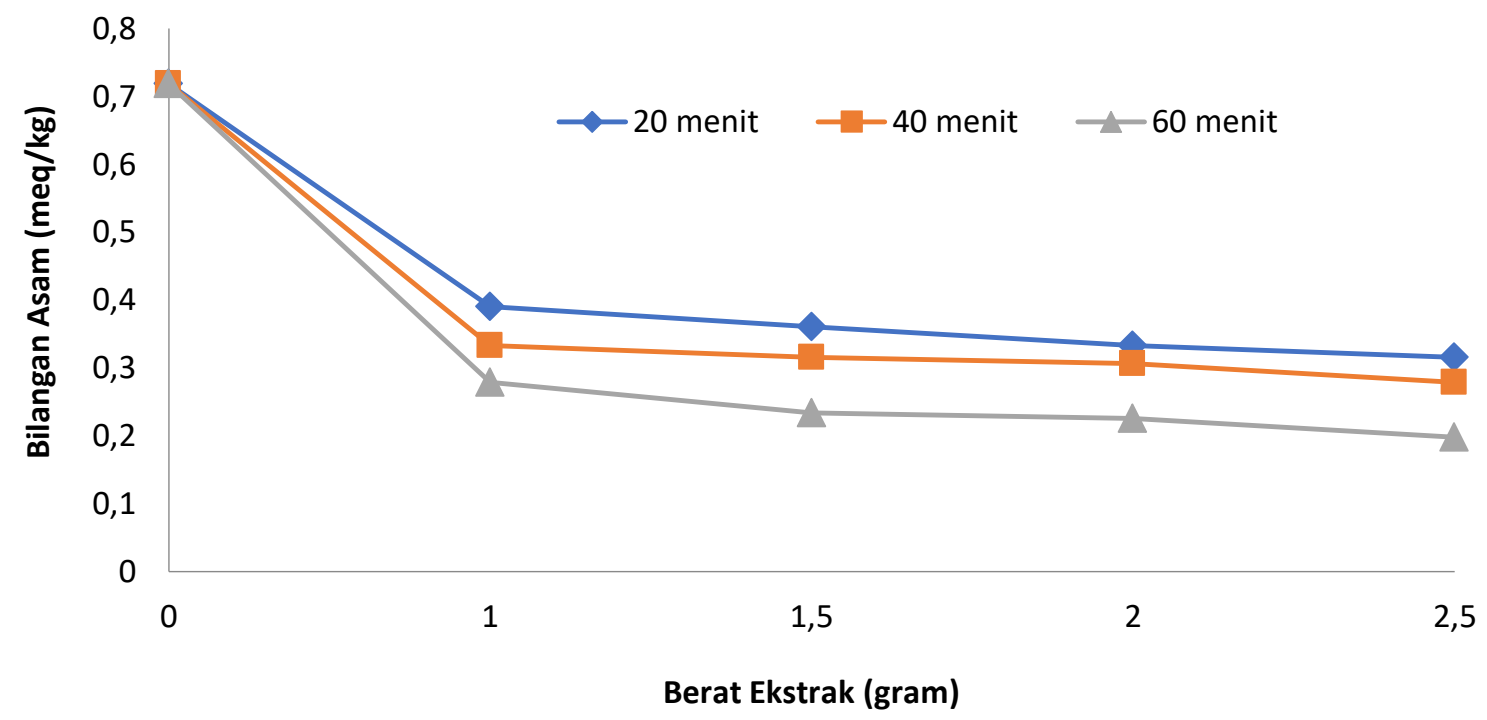

Gambar 3 Hubungan Antara Berat Ekstrak Kulit Pisang Raja Dengan Bilangan Asam Dengan Berbagai Variasi Waktu Pengadukan

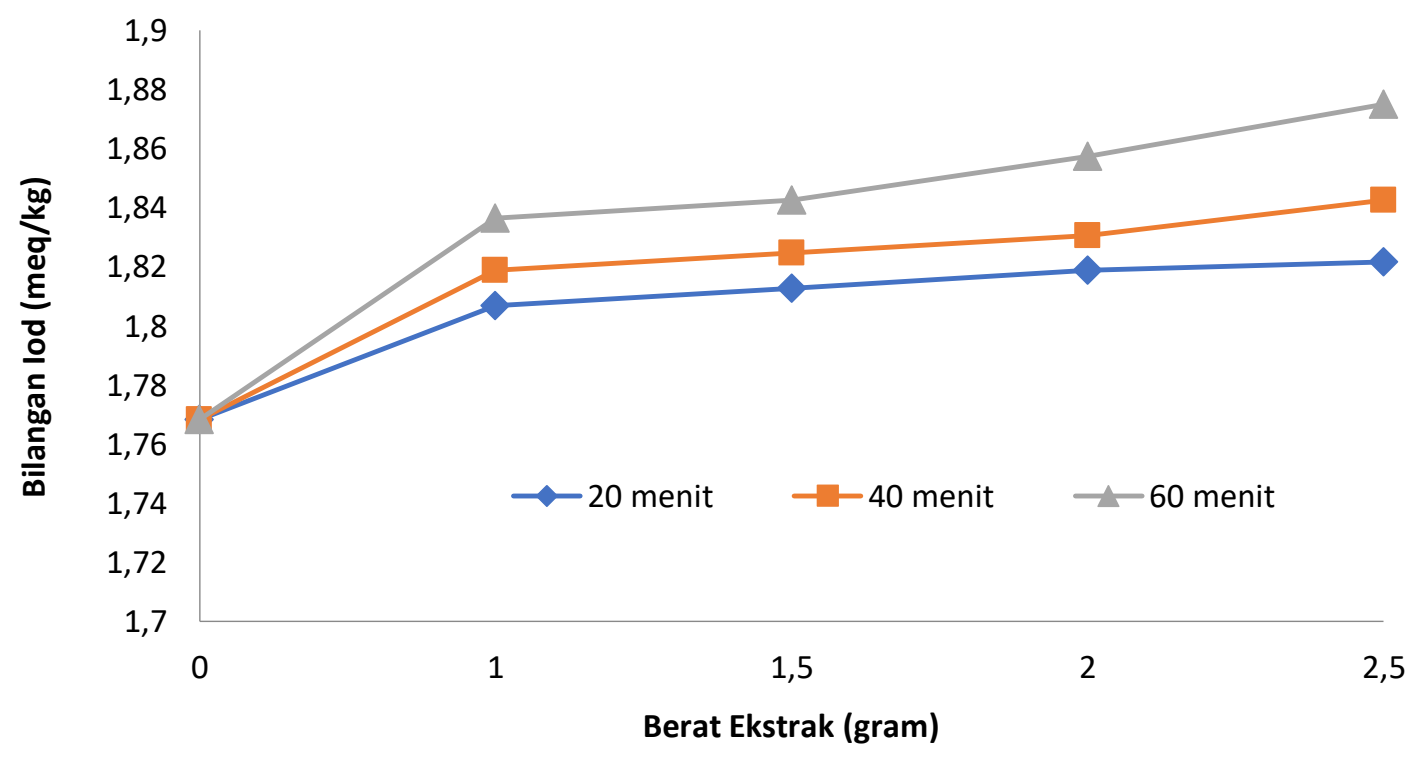

Gambar 4 Hubungan Antara Berat Ekstrak Kulit Pisang Raja Dengan Bilangan Iod Pada Berbagai Variasi Waktu Pengadukan 


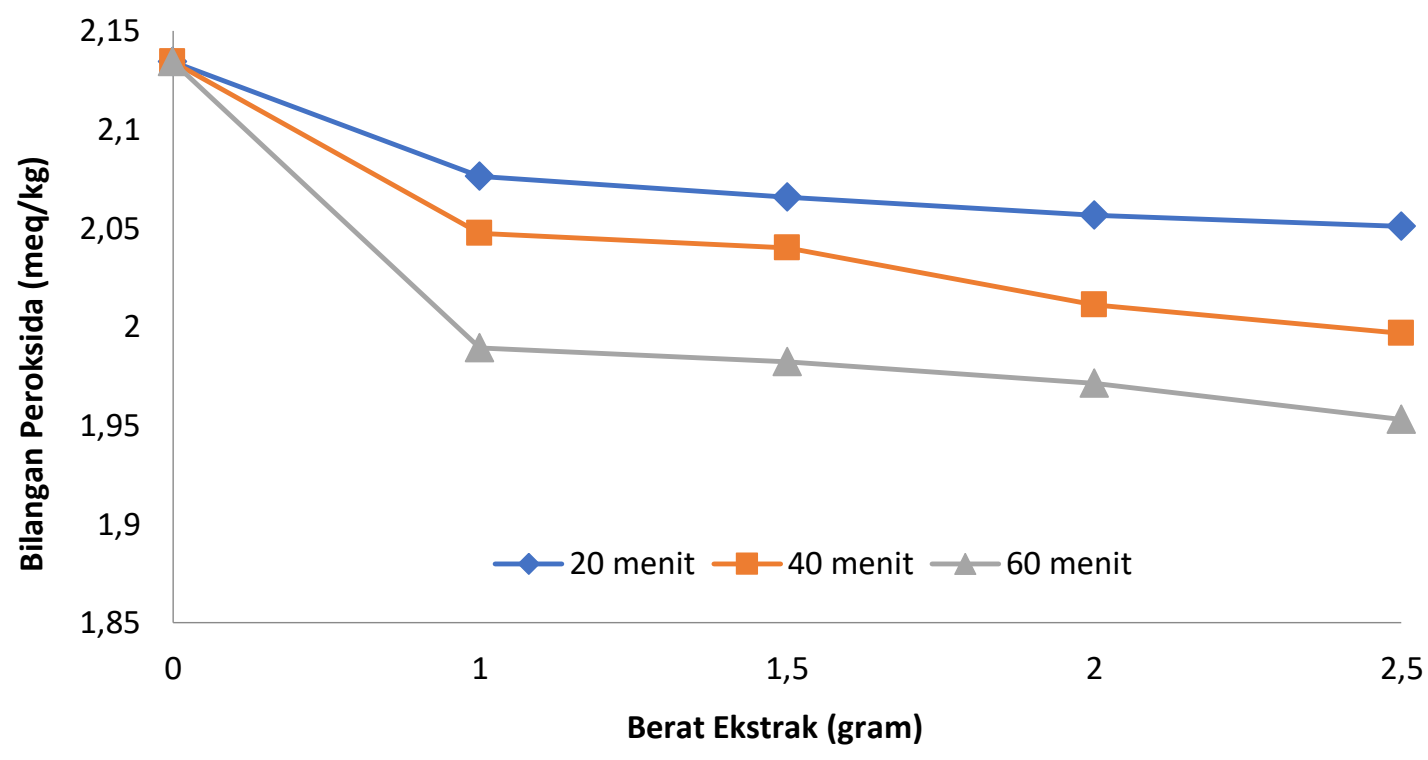

Gambar 5 Hubungan Antara Berat Ekstrak Kulit Pisang Raja Dengan Bilangan Peroksida Pada Berbagai Variasi Waktu Pengadukan

Pengaruh Penambahan Berat Ekstrak

Kulit Pisang Raja dan Waktu

Pengadukan Terhadap Bilangan Peroksida

Bilangan peroksida adalah nilai terpenting untuk menentukan derajat kerusakan pada minyak atau lemak, asam lemak tidak jenuh dapat mengikat oksigen pada ikatan rangkapnya sehingga membentuk peroksida. Hubungan antara berat ekstrak kulit pisang raja dengan bilangan pengadukan dengan berbagai variasi waktu pengadukan dapat dilihat pada

Gambar 5. Hasil terbaik pada analisa bilangan peroksida adalah dengan penambahan berat ekstrak 2,5 gram dan waktu pengadukan 60 menit yaitu sebesar 1,95320 dengan dari sebelum dilakukan penambahan ekstrak yaitu 2,12600 $\mathrm{meq} / \mathrm{kg}$, sehingga mengalami penurunan bilangan peroksida sebesar 8,123\%, penambahan ekstrak kulit pisang raja berpengaruh pada penurunan bilangan peroksida yang berarti bahwa kerusakan minyak yang diakibatkan reaksi oksidasi penyebab ketengikan dapat diperlambat.

\section{KESIMPULAN}

- Penambahan ekstrak kulit pisang raja pada minyak goreng curah dapat meningkatkan kualitas minyak goreng curah yang ditandai dengan menurunnya bilangan peroksida, bilangan asam, dan peningkatan bilangan iod.

- Hasil terbaik yang didapatkan adalah pada penambahan berat ekstrak pisang raja 2,5 gram dengan waktu pengadukan 60 menit sehingga didapat nilai bilangan asam 0,19827 $\mathrm{meq} / \mathrm{kg}$, bilangan iod 1,87500 $\mathrm{meq} / \mathrm{kg}$, bilangan peroksida 1,95320 $\mathrm{meq} / \mathrm{kg}$. 


\section{DAFTAR PUSTAKA}

[1] Anhwange, B., Ugye, T. \& T. Nyiaatagher. 2009. "Chemical Composition of Musa Sapientum (Banana) Peels". Electronic Journal of Environmental, Agricultural, and Food Chemistry

[2] Chauhan, A., Anshita N., Kumud B., dan Yas S. 2016. “Comparative Study of Different Parts of Fruits of Musa Sp. on the Basis oftheir Antioxidant Activity". Scholar Research Library

[3] Eckey, S.W.1955.'Vegetable Fat and Oil. Reinhold Publishing Corporation". New York..

[4] Gordon, I. 1994. "Functional Food, Food Design, Pharmafood". New York: Champman dan Hall

[5] Haryono. 2010. "Pengolahan Minyak Kelapa Sawit Bekas Menjadi Biodiesel".Yogyakarta: Seminar Nasional Teknik Kimia "Kejuangan".

[6] Ketaren, S. 1986. "Minyak dan Lemak Pangan”. Jakarta: Penerbit Universitas Indonesia (UI Press)

[7] Marlina, L., dan Ratnawati.2015. “ Pengaruh Penambahan Ekstrak Kulit Manggis Terhadap Ketahanan Oksidasi Minyak Goreng Curah". Tangerang: Institut Teknologi Indonesia.

[8] Pane, Elfira.2013.“Uji Aktivitas Senyawa Antioksidan dari Ekstrak Metanol Kulit Pisang Raja (Musa Paradisiaca Sapientum)".Palembang: IAIN Raden Fatah

[9] Schuler P. (1990), "Natural Antioxidant Exploited

Comercially", di Husdont BJF, Food Antioxidants, New York: Elsevier Applied Science

[10] Sheng, Zhan Whu et al. 2010. "Investigation of dietary fiber, protein, vitamin $\mathrm{E}$ and other nutritional compounds of banana flower of two cultivars grown in China".

[11] Sitepoe M. 2008. "Corat-Coret Anak Desa Berprofesi Ganda". Cet. 1. Jakarta: Kepustakaan Populer Gramedia.Hlm. 15-18.

[12] Standart Nasional Indonesia. 1998. "Cara Uji Minyak Dan Lemak". SNI 3555-998. 